\title{
Women's Status and Fertility in Finland'
}

\author{
CAROLYN C. RIZZA \\ Associate Professor \\ Department of Sociology, \\ Slippery Rock State College \\ U.S.A.
}

A dramatic increase in the number of employed married women has occurred during the past two decades in Finland. At the same time, there was a corresponding decrease in the number of children per family. The adult life of married women is now dominated by fulltime salaried work and the net reproduction rate is less than one. Finland's population is approximately 4.8 million and the continuation of such a low birthrate is perceived as a threat to the nation's longterm existence. Some Finnish experts are advocating pronatalist policies in an effort to reverse this trend. This paper investigates the relationship between the societal goal of increasing the birthrate and the impact of that goal on the status of working women in Finnish society. The Finnish situation is important to all of us since increased participation of women in the labor force of modern industrialized countries appears to result in a lower birthrate, causing a number of countries to consider pronatalist policies. But an increase in the number of children is usually associated with a traditional family lifestyle and reduced power and equality of women both inside and outside of the family. Pronatalist policies may therefore seriously erode women's recent gains in equality. If this is true, we need to consider policies and social changes which will encourage families to have children while protecting the equality of women in the work force and at home.

\section{A Changing Role}

Many researchers have noted a consistent negative relationship between fertility and the employment of women in developed countries (Kupinsky, 1977: Freedman, 1961, 1975: Hawthorn, 1970). The decline in fertility in Western Europe began around 1890 and continued with increasing momentum until the 1920's. The fertility

\footnotetext{
1 This article is based on a paper presented at the 10th Anniversary Conference of the Michigan Women's Studies Association, Ann Arbor, Michigan, April 2-3, 1982.
} 
rate stabilized during the 1930's. A temporary rise followed World War II, after which birthrates returned to their downward trend. Even more notable relationships between fertility rates and female employment levels began to emerge on the aggregate level in the 1950's. During this decade, there was a substantial increase in the number of economically active married women which was reflected in the decreasing fertility rates of the 1960's (Stolte-Heiskanen, 1977).

Aggregate-level comparisons between employment and fertility rates provide only a superficial picture of their relationship. They are also subject to the dangers of the »ecological fallacy» in their interpretation. Aggregate figures hide considerable variation between countries. For example, between 1800 and 1950 the population increased 4.9 times in England and Wales, 2.9 times in Sweden, and 1.4 times in France. Additional variations occur over time as well as between regions and classes within a given country. Despite this variation, after passing a certain threshhold, birthrates in industrialized countries seem to settle around similar low rates. Therefore, the thesis of a universal Western European historical pattern of fertility is defensible at least on a general level even though the relationship between women's participation in the labor force is far more complex than is often assumed. There is particular correspondence between female labor force participation statistics and fertility rates on the post World War II years (Stolte-Heiskanen, 1977).

One reason for this correspondence is that a Western European marriage pattern emerged at this time. Up until the 1950's a low proportion of the population was married, and those who were not did so later in life. Thus, working women were usually single women or young girls. Today more people are married and the marriages take place at an earlier age. As women marry younger, they have children earlier and the intervals between births become shorter. At the same time, female work activity is at its peak during the usual marriage age $(20-24)$. There is a gradual decline during the childbearing years, but a larger proportion of married women remain economically active and more mothers with young children work outside the home (Stolte-Heiskanen, 1977).

This new development raises the question of the compatibility of the worker role and the mother (or parental) role. For the first time in modern history work activities and home activities form the core of two separate and growing systems (Haavio-Mannila \& Kari, 1979). The women worked exclusively at home, the children were there with them. With industrialization, work moved out of the home while mothers and children remained. Now that mothers have moved into the workplace, the relationship between work and family life is becoming a major policy issue. The continuing emphasis on the changing role of women in society, has given way to a new concern. As the rise in the number of women in the labor force had consequences for men - coworkers, husbands and sons - we are beginning to see a concern with the structure of work and its relationship to both women and men. Today we are experiencing a variety of internal and external pressures on both the family and the workplace. The result may be a major reorganization of work and family life, a reorganization which some say must take place if industrialized societies are to survive (Kamerman and Kahn, 1981). 


\section{Women and Employment}

We now focus on the Finnish situation to highlight these policy issues. Finland is a special case for two reasons. First, Finland has special historical and geographic circumstances. It was part of Sweden until 1809, at which time it became an autonomous Grand Duchy of Russia. It became an independent nation in 1917, and although it has often been associated with the Soviet Union, it has more ties to the west. Its language resembles that of Estonia and Hungary. It is therefore, separated linguistically and geographically, and has characteristics lying between those of western capitalist countries and the eastern socialist ones. Although women in the labor force is a characteristic of Communist countries and women in schools is a characteristic of wealthy nations, Finland is neither Communist nor wealthy (Sawyer, 1967). It has, however, more women attending institutions of higher learning than almost any other country. In 1965, 50 percent of the students in universities were women. The participation of women in the labor force is also high. In 1980, 58.7 percent of females over 15 were economically active. This is a higher percentage of gainfully employed women than other Nordic countries, but not as high as in the Soviet Union. In 1906, Finland was the first country in Europe and the second in the world to give women the vote. At the same time, Finnish families in 1966 were more traditional in the division of household tasks than the Swedish ones, but less traditional than in the East European Socialist countries (Haavio-Mannila, 1969). Therefore, Finnish women have a large amount of work in the home even though they work outside the home, and informal sex role behavior does not correspond to formal behavior.

Finland also is a special case because, although a comparison of the trends in European countries shows no clear-cut relationship between the curves of birthrates and economic acitvity, there are two exceptions, Finland and Italy. The unique socioeconomic structures and development of these countries have produced this effect (Stolte-Heiskanen, 1977). Finland remained an agrarian society longer than other nations in Western Europe. But in the 1960's the need for labor outside agriculture grew so much that male rural to urban migrants could not fill it. Since women had been involved in work on Finland's small farms, they were accustomed to working and moved easily into the labor force (Haavio-Mannila and Jallinoja, 1980).

The great majority of this increased female labor force were married women, and in the mid 1970's a great proportion of both parents were economically active (Suominen, 1979). The employment of married women grew the fastest in the 60's and 70's when the need for labor was the greatest. In 1920, 10 percent of all married women in towns were employed. In 1950, this figure rose to 34 percent, to 45 percent in 1960,57 percent in 1970 and 65 percent in 1975. From 1950 to 1960 , mothers with children did not generally enter the workforce. But from 1970 to 1975, this situation changed decisively. In 1975, 61 percent of mothers with children under school age (0-6) were employed. Seventy-five percent of those whose youngest child was between 7 and 15 were employed, while only 55 percent of the mothers with older 
children (15 and older) were employed. This is true of women in all classes expect for the very wealthy who remain more traditional. Although part-time work is one way to combine work and home, in 1975, only 7 percent of gainfully employed Finnish women were engaged in part-time work, less than in any other capitalist country. So, the change in the work force which occurred in Finland in the sixties and seventies mainly involved married women with children. And these changes, of course, had a great impact on family life (Haavio-Mannila \& Jallinoja, 1980).

As women have entered the labor force, the birthrate in Finland has declined. Birthrates began to decline in the 1950's and have continued to do so despite efforts to raise them (Jousimaa, 1978). Thus the low birthrate followed rather than preceeded women's activities outside the home (Haavio-Mannila and Kari, 1979). The crude fertility rate in Finland in 1961 was 18.3, in 1967, 16.8 and in 1980, 13.2 per 1000 inhabitants. The proportion of families who are married couples with no children has increased in Finland since 1950 (Haavio-Mannila and Kari, 1979). Family size diminished very rapidly in the 1960's and ' 70 's.

Finland's population is still growing, however, although slowly. The growth per year between 1970 and 1980 was 0.4 percent, a rate equalled by Sweden, Denmark, Belgium and Switzerland among the European countries both Eastern and Western. The Federal Republic of Germany and Great Britain grew even more slowly at a rate of 0.2 percent, while the German Democratic Republic declined by 0.3 percent (Central Statistical Office, 1978).

\section{Worker Role and Mother Role}

Finland is regarded by some experts (Stolte-Heiskanen, 1977) to be among countries with relatively high incentives for work roles and no particular support for motherhood. The lower fertility of working women is a valid conclusion in countries like this where there is a positive orientation toward married women working, a small family size norm, and the lack of institutional structures to alleviate role conflicts around allocation of tasks between working and motherhood (Kupinsky, 1977b, Stolte-Heiskanen, 1977). The practical dilemmas working women face in addition to their different values and attitudes appear to depress fertility. The large majority of married women who work carry a double burden of competing and conflicting family tasks and responsibilities which tend to motivate them to keep their family size small (Safilios - Rothschild, 1977). »On the formal level women are relatively emancipated, but there are clear difficulties in their position at home; there is no effective child-care system organized by the society, nor do the husbands help very much at home (Haavio-Mannila, 1969: 347).» Finland is unusual in that norms support both women working and women being primarily responsible for housework and child care, worsening the role conflict they may feel. This situation has been improving, with women becoming less interested in housework and husbands increasing their share in some household tasks and child care (Haavio- 
Mannila \& Jallinoja, 1980; Jousimaa, 1978). But this change is more common in the young and in families that have no children or only one child. Fathers participate less in baby care as the number of children increases while mothers are less likely to work (Haavio-Mannila \& Jallinoja, 1980; Safilios - Rothschild, 1977). So while married women's labor force participation in Finland is one of the highest, it is also one of the most conservative and non-egalitarian in its attitudes toward women's roles in society and the family (Stolte-Heiskanen, 1977).

Finland's family policies seem advanced in comparison to many other countries, the United States included. But many Finnish women writers feel that policies supporting women's working and simultaneously being mothers are weak (StolteHeiskanen, 1977; Haavio-Mannila \& Jallinoja, 1980). We turn our attention now to these policies and services. Social policy in Finland generally follows the same lines as those in the other Nordic countries (Leskinen, 1979). Family policies can be broadly defined as all the measures that society takes that one way or another affect the family. In considering family policies it is important to take into account the societal goals that guide the policy (Stolte-Heiskanen, 1973). Here we are interested in evaluating policies with regard to goals related to optimum population size and to the status of women in society. We will be discussing both services, like day care and maternal and child health services, and income transfers, for example children's allowances and housing assistance, designed to ease the burdens of families with children.

\section{Children's Day Care}

Child care became a real problem as mothers of young children began to work outside the home. Home help is virtually nonexistent in Finland, and few families can afford to pay someone a wage and the social benefits associated with working (Jousimaa, 1978). Day care in Finland began in 1880 when Hanna Rothman founded a so-called people's kindergarten in Helsinki. This institution was supported by an allowance from a special association which got its money from the sale of alcohol. This was the beginning of the state and municipal allowance for the day care of children. In 1913 local authorities in Helsinki began to support kindergartens. The state granted money for kindergartens for the first time in 1917. This support was minor until after 1966. At this time the employment of mothers began to increase rapidly while informal mother surrogates became harder to find (Haavio-Mannila \& Jallinoja, 1980).

In the late 60 's, there was pressure to improve day care conditions. The improvement was considered necessary as a social service for working parents and as a form of early childhood education. These efforts resulted in the Children's Day Care Act of 1973 aimed at the $0-7$ year olds. The act established care after school for those children in school and play centers and childminders for those not yet in school (Suominen, 1979). Every child is entitled to a place in day care but there are not enough places for everyone. Consequently, places must be allocated according to 
priorities which include handicapped children and children of one parent families (Suominen, 1979; Jousimaa, 1978). Parents are charged for municipal day care and day care provided in families on the basis of their income (Jousimaa, 1978).

Although the number of places in day care centers has increased, the same proportion of mothers can use them, since the number of employed mothers has increased at the same rate. Some of the remaining children are taken care of by child minding (where children are taken care of in other families) since the new day care law which also granted state allowances for such care (Haavio-Mannila \& Jallinoja, 1980; Suominen, 1979). In 1974, nursery schools formed 81 percent of the total number of all municipal day-care facilities. In 1977, because of the increase in child minding, their numbers was only 70 percent (Suominen, 1979). This greater increase in family day care facilities and child minding results because construction costs are minimized (Suominen, 1979: Haavio-Mannila \& Jallinoja, 1980).

Private day care is also available. It is supervised by local authoritıes but is not subsidized by the state. It has decreased since passage of the Children's Day Care Act, but not as fast as the growth of municipal day care, indicating a growing need for child day-care (Suominen, 1979). According to the Children's Day Care Act, local authorities annually draw up a five-year plan for day care. The plans for 1979-83 indicate that, at the end of 1978, only 48 percent of the need for full and part-time day care can be filled while only 52 percent of the need for full-time day care is being satisfied (Suominen, 1979). So the public provisions of day care services remains inadequate in Finland as it is in most other countries (Stolte-Heiskanen, 1977).

\section{Other Services and Transfers}

In addition to day care, each municipality provides health care for mothers and children. The clinic provides prenatal care for the mother and the receipt of such care is a precondition for the receipt of the maternity benefit discussed below (Lindgren, 1978). Babies become clients of the child care clinic at the age of two weeks. These maternal and child care clinics are used by nearly everyone and are available free of charge. Health education and advice on contraception is also offered as is free dental care for children under 17 and for expectant mothers (Jousimaa, 1978). Other family services include marriage and family counseling clinics, and services for unwed mothers and their children (Leskinen, 1979).

In addition to services, Finland also provides for social transfers of income to level off family expenses, to facilitate the establishment of families and to ease the situation of young families in general. These transfers include a maternity allowance, a children's allowance and a municipal housing allowance. Most of the measures are financed by the state and municipalities together, but children's allowances, which are the largest item are paid for totally by the employers (Lindgren,1978).

The first maternity allowance was established by law in 1937 . This allowance is 
paid for a ten month period beginning a month before the baby is born. It equals about $70-75$ percent of an employed woman's net average daily pay. Those women who are not economically active receive a minimum allowance. The father can also take six weeks of this ten month period to stay home and help when the mother and baby come home. The child also receives either a sum of money or a box of clothes or other baby things before birth if the mother has received the required prenatal care. The box of baby things is valued at about twice the cash payment and is intended to guide the mother in the care of the baby. The cash benefit facilitates free choice and is worth about three days average industrial pay.

The Children's Allowance Act of 1948 established an allowance to be paid to all families for children under 16. This allowance is received as soon as the child is born and the amount per child increases up until the fourth child. A larger allowance is paid for children under three years of age. The value of this allowance is about ten percent of the average maintenance costs of a child. In addition, there is a tax deduction for children under sixteen years of age (Jousimaa, 1978; Leskinen, 1979; Lindgren, 1978).

Housing also presents a special problem in Finland. As early as 1949, the state promoted housing development by providing low interest, long-term loans to municipalities, corporations, and private individuals to build housing. In 1966, a new Housing Production Act established a National Housing Board. This board is responsible for the distribution of state loans and the overall programming, supervision and management of housing production. This resulted in a special emphasis on housing in the 1970's. Most of the dwellings built during this time were high rise condominiums with small dwelling units. As a result, Finland has one of the highest housing densities in Europe. In addition the lack of rental housing and cheap sinput» dwellings has meant that families must sacrifice a great deal to buy housing. Mortgages are given only for a short period of time, characteristically eight to ten years. Crowded housing obviously mitigates against having large families if other choices are available. Finland is taking steps to correct this problem. Low income families can qualify for housing assistance to provide reasonable housing without excessive cost (Leskinen, 1979; Haavio-Mannila \& Jallinoja, 1980) but this cannot help if no suitable housing exists (Lindgren, 1978).

\section{Equality as a Goal}

Despite these seemingly advanced policies, there are several aspects of Finnish life which mitigate against true equality between men and women. Different taxes for large and small families may affect the motivation of women to work outside the home. In addition, inequality of employment opportunity and differences in pay between the sexes make the wife's employment economically and emotionally subordinate to her family role (Stolte-Heiskanen, 1973). Althoug legislation between 1864 and 1929 gave women almost complete equality with men, attitudes often keep women from realizing this equality. Women are directed toward »female oriented» 
subjects at the age of 15 and again upon entering the university. The traditional burden of child care and housework places women at an additional disadvantage (Auvinen, 1970). As a result, women earn only 70 percent of what men normally earn (Jousimaa, 1978) and the employment rate for married women is lower than that for single women. It is also two-thirds that of men (Auvinen, 1970).

Equality of women is, however a goal of Finnish national policy. The Committee on Equal Rights under the auspices of the central government is charged with promoting equality between the sexes and seeing that such equality is carried out in practice (Jousimaa, 1978). One of the particular demands of Finnish women that emerged in the 60's was the right of married women to work outside the home (Haavio-Mannila \& Jallinoja, 1980). The Report of the Committee on the Position of Women in Finnish Society in 1970 categorically defined the right to gainful employment as the criteria of female independence. Work not only provides women with material resources but also opens the door to influence and a share in decision making. It is the principal means of acquiring prestige, status and self-fulfilment in Finland (Auvinen, 1976) as elsewhere (Goode, 1963; Hochschild 1975; Gillespie, 1971). However, working places demands on women which often produce conflicts between working and mothering. Although the number of children has diminished, the family has more problems taking care of them. The complex changes that produced changes in labor force participation have not brought about corresponding changes in the structure of internal divisions of labor and attitudes within the family. Obviously women will continue to work and continue to have children. We need to ask what kinds of normative and policy changes need to be instituted to achieve general societal compatibility between mother and worker roles. These policies can be concerned with the extent to which childbearing affects women's job security, how much society shares the economic burden of childbearing, and how well it provides alternative institutions for the physical care and safety of children outside the family. These services in turn depend upon a society's resources, the prevailing attitudes regarding women and their work and family roles, and the country's population policies (Stolte-Heiskanen, 1977).

All societies need children and they need to be well cared for if society is to survive. Policies designed to meet the needs of children and maintain fertility need to reflect concern for women, child care, the income of families with children, the availability of jobs, the nature of work and the allocation of time for work and home. A central question for all societies is whether or not adults can manage productive roles in the labor force at the same time that they fulfil productive roles at home. The needs of all - men, women and children - as well as the needs of society at large must be considered. The immediate policy choice is whether mothers of very young children should be expected to work, expected to remain home and care for their children, or should be permitted to choose between work and child care. Even if there is more shared responsibility between husbands and wives the pressures on working parents, especially on single parents, demands that society at large also take some responsibility for child care (Kamerman \& Kahn, 1981). Although Finland has traditional family norms at home, there seems to be public support for 
greater equality between men and women. Therefore, any new pronatalist policies should facilitate equality at work and at home, and should move in the direction of greater societal responsibility for child care. Women should be encouraged to remain in the labor force and men should be encouraged to become more involved in child care. Changing the labor market to make working more compatible with child rearing is also necessary for job and home equality. Society must bear more of the cost of children and take more responsibility for their care.

\section{To Change the Attitudes}

The last section of this paper will focus on specific policy issues with regard to changing the labor market to make it more compatible with child rearing, changing the child care available outside the home, reducing the cost of bearing children, and changing the role of men.

Western Society is ill-equipped to assist people in balancing parenting with job performance or professional achievement. Since women carry the heaviest burden of child care, many of them decide not to have children. The separation of work and family environments, begun during industrialization, should end (Shiffman, 1980). There are a number of ways employers can respond to the needs of working parents including flexible working hours, the provision of child care at work, and flexible benefits (Eisenberg, 1980). Such benefits often result in lower personnel turnover, less absenteeism, easier recruitment of new employees, and more positive attitudes toward the employer (Perry, 1979; McIntyre, 1978; LeRoux, 1980). Sweden has instituted a shorter work day for parents of young children, although without full compensation. Unless such benefits were taken by both men and women, however, such part-time work reinforces women's low status in the labor force and perpetuates the traditional division of labor at home (Wecks, 1980). Flextime can give people the opportunity to come to work earlier and leave earlier; thus enabling them to spend more time with their families. The stereotype of women dropping out of the labor force for a long period of time is erroneous. Job training, however, needs to be provided for those parents who do leave the labor force so they will not be penalized for childbearing related absences. Other policies attempted in different countries include paid sick leave to stay home with a sick child and paid personal holidays for parents. In Hungary, for example, parents of one child receive two holidays, for two children, five holidays and for three or more children, nine paid holidays (Kamerman \& Kahn 1980). These enlightened policies could make parenting easier and more attractive.

Even if work were made more compatible with childbearing, the need would still exist for child care outside the home. Insufficient child care is typical of all countries, but France has, perhaps the most completely developed system. Preschool serves 95 percent of children between ages 3 and 6 , and 32 percent of the three year olds. After school care and care during lunch and holidays are also available (Kamerman and Kahn, 1980). Child care should be more plentiful, included in plans 
for all new housing and cheaper. The major goals of child care should include both the developmental needs of the child and the needs of the family.

Children are expensive. If children are a national resource, society should be willing to share some of the cost of bearing them. Benefits should be designed to transfer income from childless families to those with children since a family's standard of living falls with each additional child. Another policy objective in some countries is to transfer income to poorer families. These policies, however, only encourage poor parents, usually women, to drop out of the labor force and thus reinforces their subordinate role. Payments should be made regardless of labor force participation, since one objective is to encourage women to remain in the labor force. Policies could include more generous children's and maternity allowances. Allowances can also be made for those parents who stay at home to care for young children and suffer a loss of earnings. These benefits need to be wage related. If not, it pays only poor women to stay home, again reinforcing their subordinate role. Such allowances could also be made available for grandparents or other relatives who care for children. This kind of policy has already begun with payments to childminders. If such allowances were included in taxable income, it would help in reducing income inequalities.

Housing is a difficult problem. Cheap housing is hard to find and units are usually small. Tenants for public housing are typically chosen on the basis of social criteria. Public housing for sale is being built but the ceiling on the prospective buyers income is low and the size of publically financed housing is regulated in accordance with a one person-one room principle (Jousimaa, 1978). Housing units must be made larger and less expensive. Since mortgages are, by U.S. standards, short-term, the length of time to pay a mortgage could be extended considerably.

A more equitable division of household and child care tasks between men and women is also necessary. As suggested earlier, Finland is particularly traditional in this regard. Therefore, all child care and homemaking benefits now granted to female employees should be granted to men. Incentives should also be devised to encourage men to take advantage of them. Unfortunately, a recent experiment in public policy focused on a »mothers wage» to determine how many women would stay home if they were paid a wage out of public funds and how large such a wage should be (Jousimaa, 1978). Encouraging equality between men and women will require major rethinking in both policy and research. Most of the research on the relationship between women's labor force participation and fertility assumes that it is a problem for women only. No mention is made of the husbands impact on decisions to have children. It is as if he did not exist. We know next to nothing about the father's impact on the decision to have children and what causes some men to want many children and some to want only a few - or even none. More research needs to be carried out in this critical area. All entitlements must be parent entitlements. Both parents need to receive leaves. Policies in Finland, like those in Sweden, are beginning to reflect these ideas, but there is a difference between making such benefits available to both men and women and encouraging men to take advantage of them. Some countries give benefits contingent upon the receipt of 
prenatal care. Benefits can be made contingent on the participation of the father as well.

In summary, in an advanced industrialized society that accepts womens working, lower levels of fertility are likely to result; if female employment offers alternative satisfactions to motherhood and such employment is not amenable to the combination of mother and worker roles and inexpensive child care is not available. Professional women in particular, are more likely to see children as interfering with employment (Beckman, 1978). This finding suggests continuing lower fertility rates as women become progressively more equal in occupational status. From the demographic point of view, in an increasing number of countries, whether or not women will be willing to continue to give birth to children is an important question. The answer partially depends on what facilitating conditions are offered by society. Behavior and attitudes relating to the family also will affect the willingness of people to have children. The feminist agenda for the 80 's will be to restructure both home and work. The rigid sex role stereotyping perpetuated by the division of labor in the traditional family is not appropriate for the demands that either sex will have made on them as adults. We must move in the direction of both more equality and a greater congruence between home and work for everyone.

\section{References}

Auvinen, Riitta: Women and Work (II): Social Attitudes and Women's Careers. Impact of Science on Society 20(1): 73-83, 1970.

Auvinen, Riitta: Women and Decision-making: A Social Science Priority. Institute of Social Policy, University of Helsinki, Research Reports, No. 1, 1976.

Beckman, L. J.: The Relative Rewards and Costs of Parenthood and Employment for Employed Women. Psychology of Women Quarterly 2 (Spring): 215-234, 1978.

Central Statistical Office of Finland: Finland in Figures. Helsinki 1978.

Eisenberg, R.: How Employers Can Help. Money (November): 89—92, 1980.

Freedman, R.: The Sociology of Human Fertility: A Trend Report and Bibliography. Current Sociology 10-11: 35-121, 1961 .

Freedman, R.: The Sociology of Human Fertility. An Annotated Bibliography. New York 1975.

Gillespie, Dair L.: Who has the Power? The Marital Struggle. Journal of Marriage and the Family 33: 445-58, 1971.

Goode, William H.: World Revolution and Family Patterns. New York 1963.

Haavio-Mannila, Elina: Position of Finnish Women: Regional and Cross-National Comparisons. Journal of Marriage and the Family (May): 339-347, 1969.

Haavio-Mannila, Elina \& Jallinoja, Riitta: Changes in the Life Patterns of Families in Finland. Department of Sociology, University of Helsinki, Working Papers, No. 13, 1980.

Haavio-Mannila, Elina \& Kari, Kyllikki: Demographic Background of Changes in the Life Patterns of Families in the Nordic Countries. Department of Sociology, University of Helsinki, Working Papers, No. 11, 1979.

Hawthorn, G.: The Sociology of Fertility. London 1970. 
Hochschild, Arlie Russell: The Sociology of Feeling and Emotion: Selected Problems. In Marcia Millman \& Rosabeth Moss Kanter (Eds.): Another Voice: Feminist Perspectives on Social Life and Social Science, pp. 280-307. Garden City, New York 1975.

Jousimaa, Kaarina: Finland - A Scandinavian Modern Country. Helsinki: Finnish-American Cultural Institute. Helsinki 1978.

Kamerman, Sheila B. \& Kahn, Alfred J.: Child Care, Family Benefits and Working Parents. New York 1981.

Kupinsky, Stanley: The Fertility of Working Women in the United States: Historical Trends and Theoretical Perspectives. In Stanley Kupinsky (Ed.): The Fertility of Working Women, pp. 188-249. New York 1977.

Kupinsky, Stanley: Overview and Policy Implications. In Stanley Kupinsky (Ed.): The Fertility of Working Women, pp. 369-380. New York 1977.

LeRoux, M.: Day Care Center Nurtures Savings, Worker Goodwill. Business Insurance 14 (Dec. 15): $3+, 1980$.

Leskinen, Jyrki (Ed.): Facts about Finland (16th ed.). Helsinki 1979.

Lindgren Jarl: Family Policy as a Field: Finland. In Sheila Kamerman \& Alfred J. Kahn (Eds.): Family Policy: Government and Families in Fourteen Countries, pp. 270-294. New York 1978.

McIntyre, K. J.: Day Care: An Employer Benefit, Too, Business Insurance 12 (December 11): 11, 1978.

Perry, S. K. S.: Survey and Analysis of Employer-sponsored Day Care in the United States. Unpublished doctoral dissertation, University of Wisconsin-Milwaukee, March 1979.

Safilios-Rothschild, Constantina: The Relationship Between Women's Work and Fertility: Some Methodological and Theoretical Issues. In Stanley Kupinsky (Ed.): The Fertility of Working Women, pp. 355-368. New York 1977.

Sawyer, Jack: Dimensions of Nations: Size, Wealth and Politics. American Journal of Sociology 73: $145-172,1967$.

Schiffman, S.: Making it Easier to Be a Working Parent. New York Times, November 24: 27, 1980.

Stolte-Heiskanen, Veronica: »Holistic» vs. "Particularistic» Approaches to Family Policy. Institute of Sociology, University of Helsinki, Research Reports, No. 187, 1973.

Stolte-Heiskanen, Veronica: Fertility and Women's Employment. In Stanley Kupinsky (Ed.): The Fertility of Working Women, pp. 250-280. New York 1977.

Suominen, Leena: Lapsiperhe Suomessa. (Facts about the families with children and the economical activity of parents in Finland). Helsinki 1979.

Wecks, W.: Part-time Work: The Business View on Second-class Jobs for Housewives and Mothers. Atlantis 5 (Spring): 69-88, 1980. 